\title{
Moose Mountain Trip
}

\author{
Mrs. John Hubbard, Grenfell, Sask.
}

The blacktop has cut a wide swathe thru' the prairie and sometimes I wonder if it hasn't taken some of the picturesqueness from the countryside. In its wide bare ditches excess rain had cut channels of their own when we travelled along it to Whitewood early in November. There was more water than ever in the sloughs, a thin layer of ice on the sloughs, and on the ice muskrats sunning themselves - fat lumps of fur.

Harvest was still progressing in spots, a threshing outfit, a combine and several balers. And in the fields the same evolution, stooks, swathe and (the new look) bales both round and square.

At Whitewood we turned south on an older highway. A weasel shot across the road, pure white and startling against snowless ground. No traffic victim this fast moving little animal.

Crossing the Pipestone we actually found it labelled with a single unelaborative sign "Pipestone Creek". Not so Moose Mountain Creek and the Souris River (Jubilee Committees please note).

Our introduction to the Moose Mountains was a thickening of the bush and an increase of slough and hill. Then mile on mile of white trunked poplars splotched with black, with here and there the buffy-pink and white of birch. Glimpses of water thru' the trees. An oil well, its machinery working - again the evolution, first the yellow gold and now the black.

Then out of the Moose Mountains and we were looking down on the plains, smoky blue in the distance, flat and fertile. And farther south the even more fertile Oxbow plains.

We crossed Moose Mountain Creek with its low rounded grassy banks, scanty trees and stony bed. And south of Oxbow we ended our southward journey at ranch buildings perched precariously on the banks of the Souris, dropping almost perpendicularly into a small yard and giving thanks for good brakes.
Coming back we viewed the Moose Mountain Range from a distance and spotted one bare peak above the rest of the hills - White Bear Mountain?

Twilight and Whitewood's skyline of elevators and trees against a grey fall sunset brought back memories of a grimmer trip earlier that fall. A stormy winter sky black with snowclouds, the sun sinking in a ball of flaring red, and against this small brilliance in the flat vastness of the Regina plains in black and perfect silhouette, the Legislative Buildings. A picture long to be remembered.

And our count in wildlife for the trip? Besides the muskrats, which were plentiful, and the weasel we saw two flocks of snowbirds, one chickadee, several flocks of pidgeons, many magpies, one male marshhawk and two or three unidentified small birds.

\section{Pectroglyphs}

By J. Turnquist, Wallwort, Sask.

While visiting at Nanaimo, on Vancouver Island, I had a trip to Petroglyphs Park. It got its name from the strange carvings on the sandstone rocks. I spent some time there copying them on paper. They are interesting in that the people who put them there had so much to tell on the designs, probably written at various times, under conditions that we do not understand today. A bronze plaque explains that mystery surrounds the origin and meaning of the rare rock carvings found in the park.

Indians of this area first showed them to the white man in 1860 , but even they were unable to interpret the strange examples of aboriginal art. I also had a trip by boat to Jack's point, where on a lone rock there are pictured four fish and one bird - a real masterpiece - and it has not been spoiled by white man's initials and names. I saw one place where some party had had a campfire on one of the rocks with carvings on it. How thoughtless some people are! 